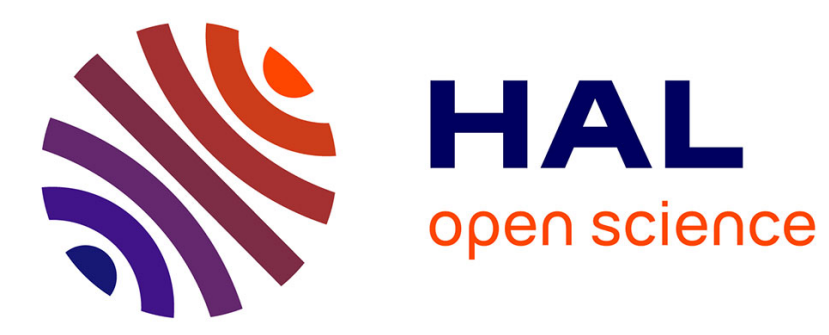

\title{
MAPPING WATERLOGGING OF SOILS USING DIGITAL TERRAIN MODELS
}

Ph Merot, B. Ezzahar, Christian Walter, P. Aurousseau

\section{To cite this version:}

Ph Merot, B. Ezzahar, Christian Walter, P. Aurousseau. MAPPING WATERLOGGING OF SOILS USING DIGITAL TERRAIN MODELS. Hydrological Processes, 1995, 9 (1), pp.27 - 34. 10.1002/hyp.3360090104 . hal-02065578

\section{HAL Id: hal-02065578 https://hal.science/hal-02065578}

Submitted on 13 Mar 2019

HAL is a multi-disciplinary open access archive for the deposit and dissemination of scientific research documents, whether they are published or not. The documents may come from teaching and research institutions in France or abroad, or from public or private research centers.
L'archive ouverte pluridisciplinaire HAL, est destinée au dépôt et à la diffusion de documents scientifiques de niveau recherche, publiés ou non, émanant des établissements d'enseignement et de recherche français ou étrangers, des laboratoires publics ou privés. 


\title{
MAPPING WATERLOGGING OF SOILS USING DIGITAL TERRAIN MODELS
}

\author{
Ph. MEROT, B. EZZAHAR* ${ }^{*}$ C. WALTER AND P. AUROUSSEAU \\ Laboratoire de Recherche de la Chaire de Science du Sol, INRA-ENSA, 65 Route de Saint Brieuc, \\ 35042 Rennes Cedex, France
}

\begin{abstract}
Maps of the potential waterlogging of soils were generated using hypotheses about the effect of topography on the soil water regime inspired by Beven and Kirkby's concept of saturation overland flow. The procedure was validated by comparing the simulated maps with maps derived from a $1: 25000$ soil survey for two contrasting catchments. The value and limitations of the method are discussed in the light of this comparison. The approach proposed here is relevant to modelling the distribution of intensely waterlogged soils, provided the relationship between bedrock and the limit values is established. This approach can be used for several purposes: (1) to distinguish positional waterlogging from other types of waterlogging; (2) to control the quality and consistency of waterlogging maps; and (3) to create soil water regime maps for non-surveyed catchments. Conversely, soil water regime maps can be compared with contributing areas simulated by hydrological distributed models for validation purposes.
\end{abstract}

KEY WORDS Geomorphology Waterlogging Digital terrain model Contributing areas

\section{INTRODUCTION}

The hydromorphic characteristics of waterlogged soils are a result of an excess of water. Permanent or temporary waterlogging induces anoxic conditions (Duchaufour, 1983), which causes the mobilization and segregation of iron via redox reactions. The soil water regime is a major criterion used in soil surveys, especially in Western Europe, because it is widespread and significantly affects land-use potential (Jamagne, 1967; Thomasson et al., 1975; Marsman and De Gruijter, 1986; Rivière et al., 1992).

The major causes of an excess of water are: rainfall on soils with poor internal and external drainage; an additional superficial or deep water supply; and the influence of humans (embanking, surface or subsurface compaction by cattle or ploughing; Vizier, 1990).

The location of soils in the landscape is important for the development of hydromorphic characteristics: waterlogged bottomland soils and poorly drained plateau soils are common. This is particularly so in Brittany as a result of the relief and the loamy texture of the soils.

The aim of the work reported here was to study how far the spatial distribution of soil affected by 'positional waterlogging' (i.e., that due to its location in the landscape) can be modelled with digital topographic data using the concept of contributing area (Beven and Kirkby, 1979; Beven and Wood, 1983).

\section{MATERIALS AND METHODS}

\section{Description of soil water regime}

Information about the soil water regime collecting during a soil survey is structured into nine classes (Rivière et al., 1992).

\footnotetext{
* Present address: CEREG, Université Louis Pasteur, 3 rue de l'Argonne, 67083 Strasbourg, France
} 


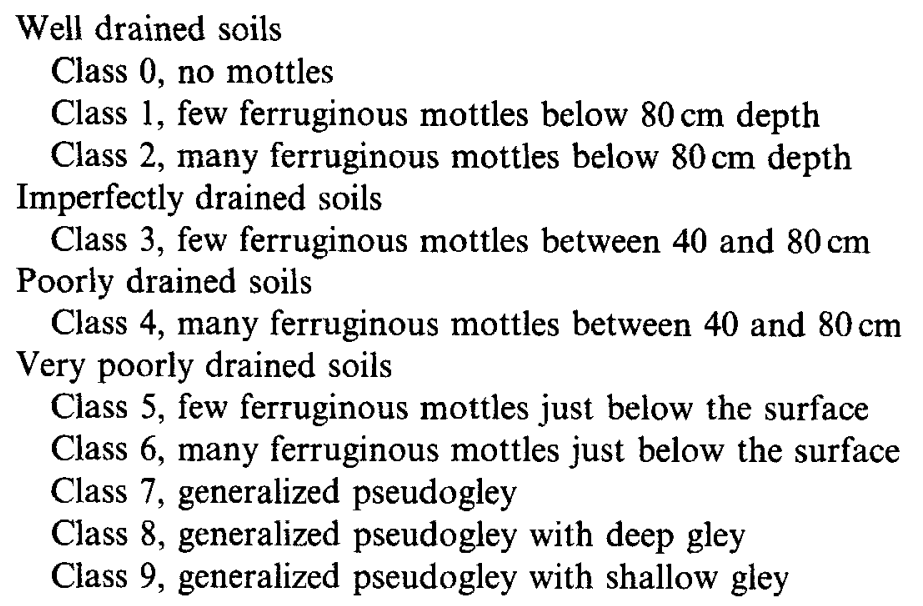

The change from class 3 to class 4 corresponds to what is considered to be more significant soil wetness.

Positional waterlogging depends on two topographic factors: (1) the local slope angle - for a waterlogged soil the local hydraulic gradient required to drain the soil is equal to the local slope angle and a moderate slope induces limited lateral drainage; and (2) the drainage area - this determines the surface and subsurface water input added to the local rainfall and is delimited by the steepest slope lines converging on the point considered.

The probability of waterlogging increases with the contributing draining area and decreases with increasing local slope angle.

\section{Contributing area concept}

The contributing area concept was first proposed by Cappus (1960; in Merot, 1988), followed by Betson (1964) and was developed by various workers (see Kirkby and Chorley, 1969; Hewlett, 1974; Hewlett and Troendle, 1975; Ward, 1982; Moore et al., 1986; 1992). According to this concept, the catchment area does not contribute to overland flow equally; overland flow occurs mainly in contributing or variable source areas, where saturation and groundwater outflow occur. The location of these areas depends on the water route convergence, slope and soil permeability. This process is called 'saturation overland flow' and 'return flow'.

A model of the relationship between the dynamics of the contributing area and topography was proposed by Beven and Kirkby (1979) and Beven (1986a; 1986b). This model is based on the hypothesis that the hydraulic gradient of the shallow water-table is equal to the topographic slope angle. Two indexes are proposed: the topographic index is given by $\log (a / \tan \beta)$, where $a$ is the drainage area per unit contour length and $\beta$ is the local slope angle; the soil-topography index or wetness index (Moore et al., 1986) is given by $\log \left(a / T_{0} \tan \beta\right)$, where $T_{0}$ is the transmissivity to the surface when the soil is saturated. This approach was notably included in a physically based semi-distributed hydrological model called TOPMODEL. Beven and Kirkby made the assumption that the hydrological behaviour of two points with the same index value is identical. This index can be used to predict the local soil saturation deficit. When the deficit is equal to zero, the soil is saturated. Consequently, the catchment is separated into two areas with different hydrodynamic behaviours: a saturated contributing area where quickflow occurs and an unsaturated area were infiltration occurs. The size of the two areas varies and depends on permanent factors (soil, topography) and on the initial and boundary conditions (the rainfall events).

\section{Methods}

The spatial distribution of soils with position waterlogging, such as the distribution of contributing areas, is explained by two topographic factors, local slope and drainage area, and by soil transmissivity and rainfall. If the model of Beven and Kirkby (1979) is applicable, areas with a high topographic index should generally correspond to waterlogged soils. Here, a comparison is made between a soil map indicating 
the distribution of waterlogging and a 'wetness' map constructed using a topographic index. The comparison is based on the statistical distribution of the occurrence of waterlogged soils and of the index values.

The topographic index is a continuous variable. Relevant index class limits relating to the soil water regime must be defined: the correspondence between soil water regime classes and index values is not known a priori. The following procedure was adopted. First, the relative area of each soil water regime class on the soil map was calculated to determine a statistical areal distribution; second, the values delimiting the index classes were selected to reproduce the same distribution of relative areas; the final check consists in comparing the map derived from the soil water regime classes and the map derived from index value classes.

To compute the topographic index, a $40 \mathrm{~m}$ grid digital terrain model (DTM) was derived from 1:25000 IGN maps (the French equivalent of the UK Ordnance Survey maps) using a scanner and the MNTSURF software (Squividant, 1992), implemented at the INRA/ENSA Soil Science Laboratory, Rennes. The catchment limits and the $a$ and $\beta$ parameters were then computed using the TOPMODEL utilities (Quinn et al., 1991).

\section{Study area}

Two contrasting sites were selected. The Crac'h coastal catchment, located in the Golfe du Morbihan, on the south coast of Brittany, has an area of $54 \mathrm{~km}^{2}$. The main stream is $19 \mathrm{~km}$ long. The slopes are gentle: the median slope angle is $0.8^{\circ}$ and the maximum slope angle is $11.6^{\circ}$. The altitude range is $6.6-53.4 \mathrm{~m}$ above sea level. The bedrock is granite and the western part of the catchment consists of an extensive plateau. The mean annual rainfall is $700 \mathrm{~mm}$ and the mean annual effective rainfall is $300 \mathrm{~mm}$.

The Kervijen coastal catchment, located in the Baie de Douarnenez in the western tongue of Brittany, has an area of $44 \mathrm{~km}^{2}$. The main stream is $17 \mathrm{~km}$ long. The slopes are steeper than in the Crac'h catchment, with a median slope of $3.1^{\circ}$ and a maximum of $18.4^{\circ}$. The altitude range is $1.7-242 \mathrm{~m}$ asl. The bedrock is Brioverian shale. The mean annual rainfall is $1050 \mathrm{~mm}$ and the mean annual effective rainfall is $500 \mathrm{~mm}$.

A 1:25000 soil survey was carried out in both the catchments.

\section{RESULTS}

\section{Soil data analysis}

Figure 1 presents the proportion of the area occupied by each soil water regime class in the two catchments.

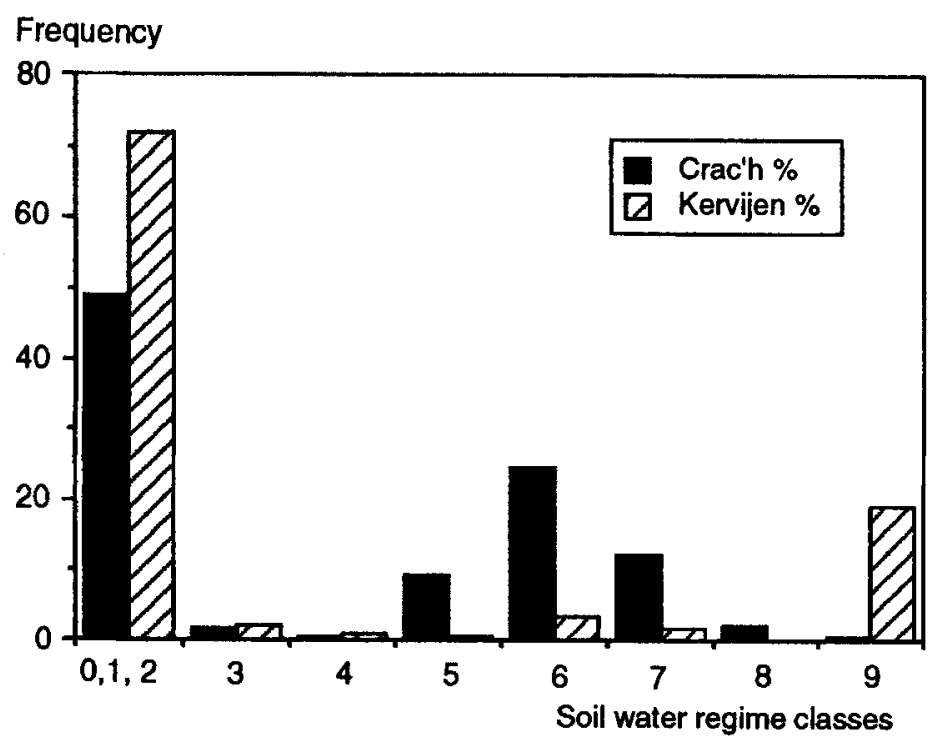

Figure 1. Proportion of soil area in each soil water regime class for the two catchments 
The figure shows two main features. (1) Some soil water regime classes have only a limited occurrence. This is so for classes 3 and 4 in the Crac'h catchment and classes 3, 4 and 5 in the Kervijen catchment. The soils are either well drained (classes 0,1 and 2) or very poorly drained (class 5 and higher); the areas associated with classes 8 and 9 in the Crac'h catchment and with class 8 in the Kervijen catchment are also very small. (2) The spatial distribution of waterlogged soil units in the landscape is very different in the two catchments (Figure 2). In the Crac'h catchment, soils of classes 7, 8 and 9 form wide strips in the valley bottom. Conversely, in the Kervijen catchment, soils of classes 7, 8 and 9 form thin strips in the valley bottoms and soils of classes 5 and 6 are extensive on the plateaux. Moreover, the wet area is larger in the Crac'h catchment than in the Kervijen catchment ( 48.8 and $25.5 \%$, respectively, of soils in class 5 and higher); conversely, waterlogging is more intense in the Kervijen catchment. This is shown by the importance of class 9 soils in Kervijen and of class 6 soils in Crac'h.

\section{Statistical distribution of the topographic index}

Figure 3 shows the cumulative areal distribution of the topographic index for the two catchments. The Crac'h catchment exhibits more high index values than the Kervijen catchment. This suggests more potentially saturated areas in the Crac'h catchment.
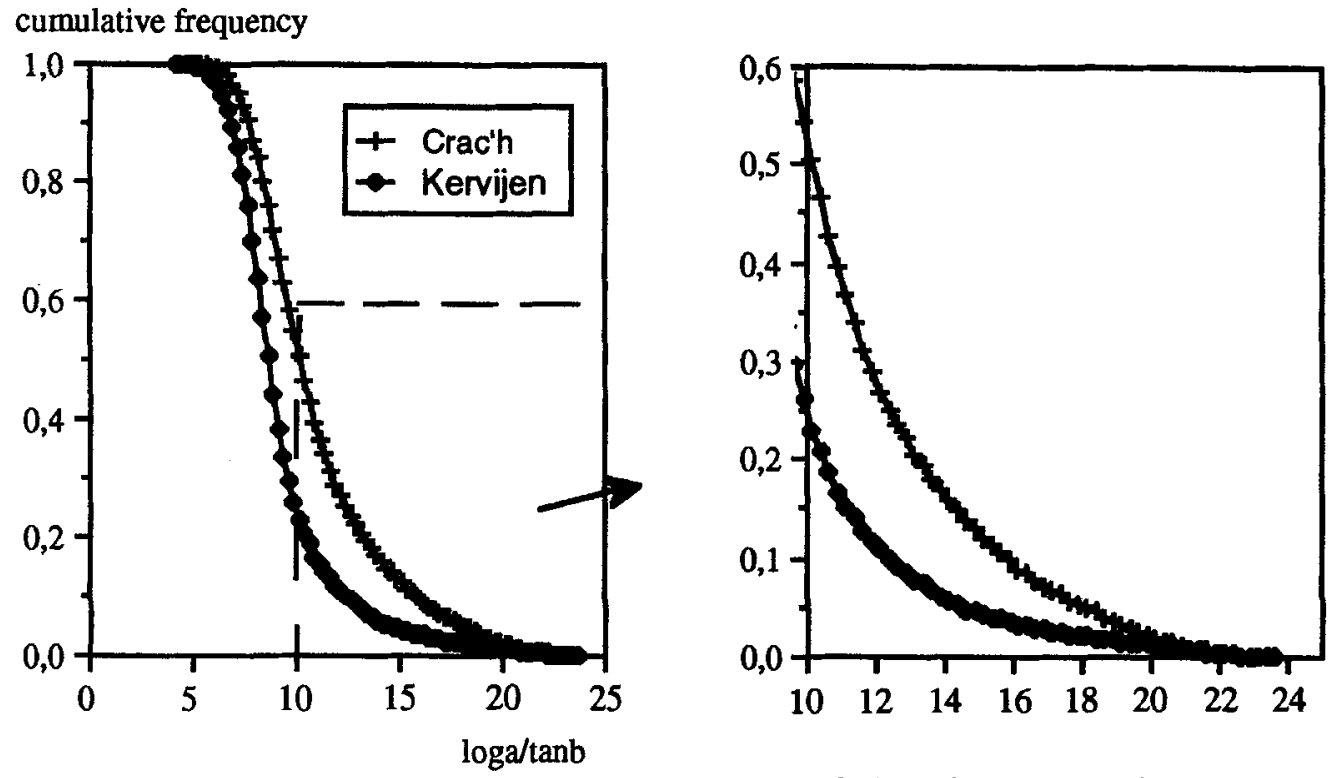

Figure 3. Statistical distribution of the topographic index of Kirkby for the two catchments

Table I. Comparison between the limits of the soil water regime classes and the values of the topographic index

\begin{tabular}{|c|c|c|c|c|}
\hline $\begin{array}{l}\text { Soil water } \\
\text { regime } \\
\text { classes }\end{array}$ & $\begin{array}{c}\text { Corresponding } \\
\log (a / \tan \beta) \\
\text { index; Crac'h }\end{array}$ & $\begin{array}{c}\text { Corresponding } \\
\log (a / \tan \beta) \\
\text { index; Kervijen }\end{array}$ & $\begin{array}{l}\text { Cumulated } \\
\text { distribution } \\
\text { Crac'h }(\%)\end{array}$ & $\begin{array}{c}\text { Cumulated } \\
\text { distribution } \\
\text { Kervijen (\%) }\end{array}$ \\
\hline $0,1,2$ & $10 \cdot 10$ & 9.67 & 100 & 100 \\
\hline 3 & & $9 \cdot 96$ & $50 \cdot 98$ & 27.87 \\
\hline 4 & $10 \cdot 24$ & & $49 \cdot 24$ & $25 \cdot 54$ \\
\hline 5 & 10.91 & & 48.79 & $24 \cdot 70$ \\
\hline 6 & $13 \cdot 37$ & $10 \cdot 37$ & $39 \cdot 27$ & 24.09 \\
\hline 7 & $19 \cdot 62$ & & $17 \cdot 73$ & $20 \cdot 64$ \\
\hline 8 & & $10 \cdot 57$ & 2.48 & 18.86 \\
\hline 9 & & & 0.42 & 18.86 \\
\hline
\end{tabular}




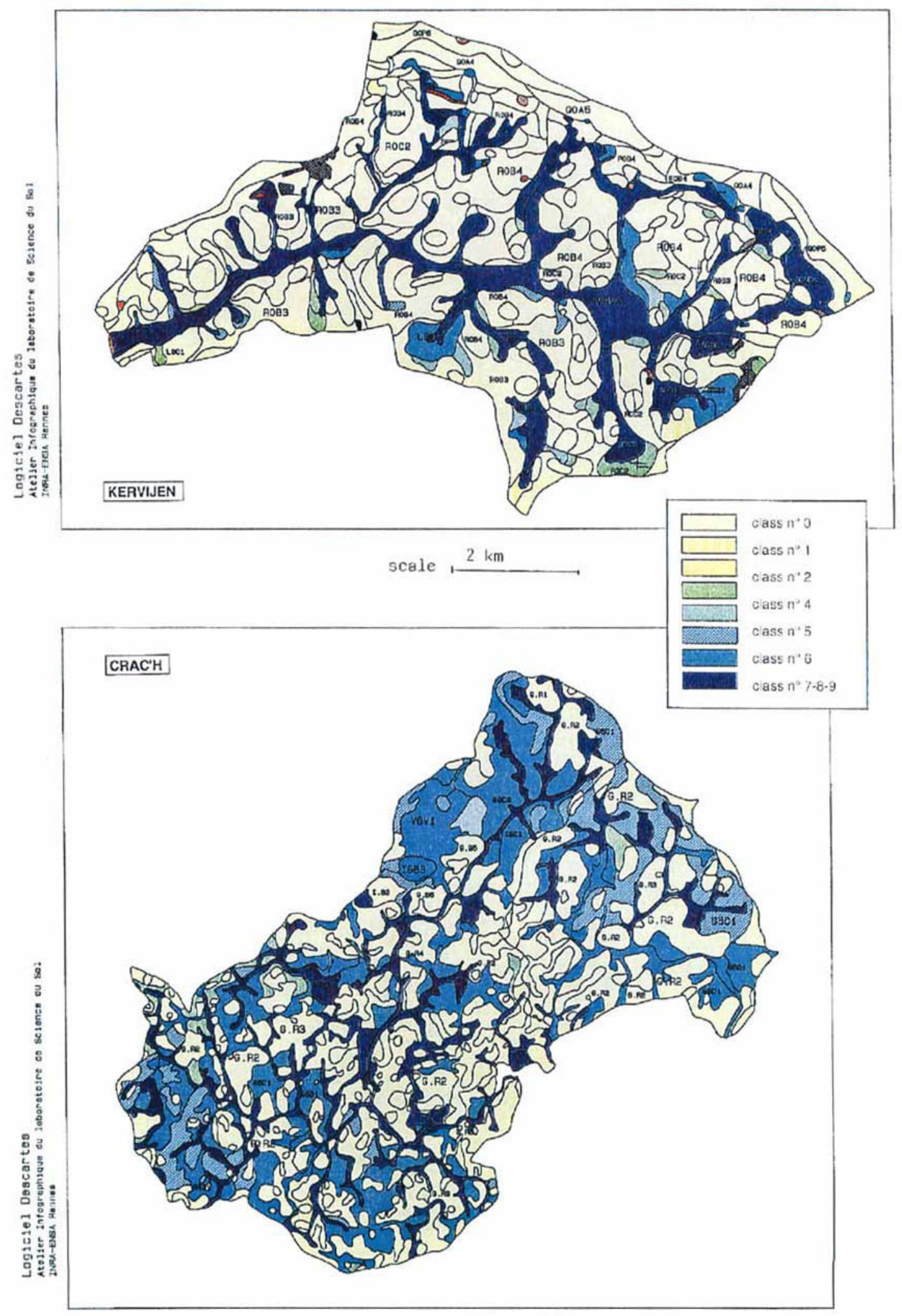

Figure 2. Soil water regime soil maps for (a) the Kervijen catchment and (b) the Crac'h catchment 

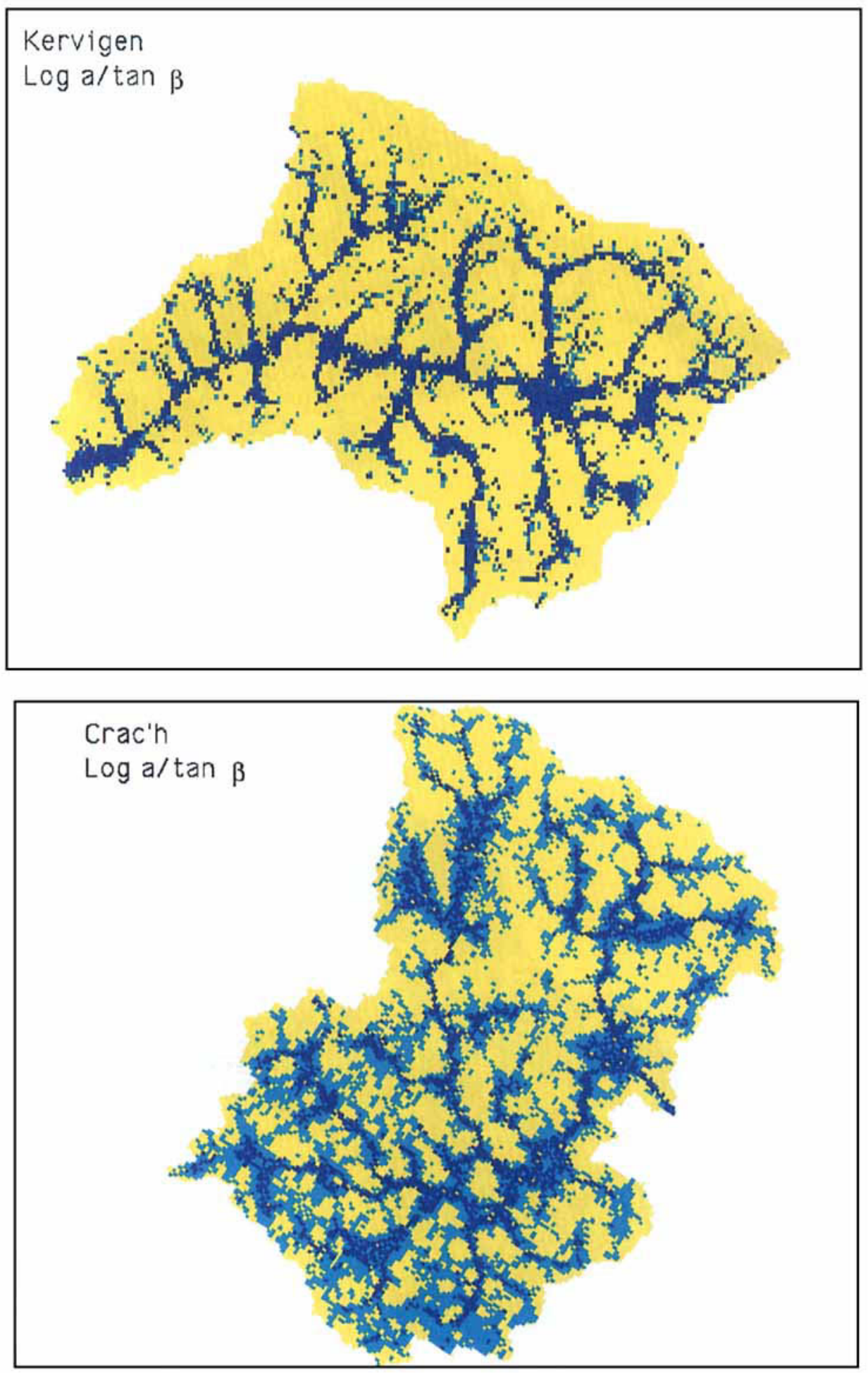

Figure 4. Maps of the topographic index of Kirkby (the deformation of the catchment is due to the printing procedure) for (a) the Kervijen catchment and (b) the Crac'h catchment (the outlet of this catchment is further downstream than on the soil map) 
Table II. Contingency table between the different classes of the soil and the wetness maps constructed with the topographical index for the Kervijen catchment, expressed as number of cells

\begin{tabular}{lrrrrr}
\hline Soil classes & \multicolumn{4}{c}{ Classes deducted from the topographical index } & Total \\
\cline { 2 - 5 } & $1,2,3$ & 4,5 & 6 & $7,8,9$ & \\
\hline $1,2,3$ & 8662 & 324 & 191 & 990 & 10167 \\
4,5 & 424 & 73 & 60 & 219 & 776 \\
6 & 129 & 19 & 22 & 254 & 424 \\
$7,8,9$ & 1075 & 133 & 236 & 1846 & 3290 \\
Total & 10290 & 549 & 509 & 3309 & 14657 \\
\hline
\end{tabular}

\section{Comparison of the distribution of soil water regime classes and index values}

The continuous distribution of the topographic index is classified. The limits of the classes are chosen such that the same proportion of catchment area as the soil water regime classes is obtained (Table I). Index values for scarcely represented soil water regime classes have not been indicated. For the Crac'h catchment, the soil water regime classes 3,4 and 5 correspond to a small variation of the index value (from 10.1 to 10.9); moderate to intense waterlogging correspond to a much larger range of index values. For the Kervijen catchment, the range of the index values for soils from classes 3-8 is small (from 9.7 to 10.6); these classes represent a small part of the catchment. Intensively waterlogged soils (class 9 ) and freely drained soils (classes 0,1 and 2 ) correspond to a large range of index values $(10 \cdot 6-24$, and 5-9.7, respectively).

The correspondence between soil water regime classes and index value classes is not the same for the two catchments, except for the freely drained soils. The limits of the index classes corresponding to classes 3,4 and 5 are not easy to determine precisely because of the small range of variation. This is not important in the Kervijen catchment where the soils are either well drained or very poorly drained. For the Crac'h catchment, two groups of soil water regime classes are important: freely drained soils (classes 0,1 and 2) and poorly drained soils (classes 5, 6 and 7). For classes 6 and 7, the limit index values are well identified.

\section{Comparison of soil water regime maps and topographic index maps}

The statistical results were used to draw maps of potential soil water regime, based on three topographic index classes; these maps were compared with the soil water regime maps, derived from the soil survey, where the poorest drained classes $(7,8$ and 9 ) have been regrouped into one unit; these two maps have been compared visually.

In the Kervijen catchment (Figures $2 \mathrm{a}$ and $4 \mathrm{a}$ ), the agreement of the two maps seems to be very good for the following index classes: $<9 \cdot 9,9 \cdot 9-10 \cdot 3$ and $>10 \cdot 3$. For the Crac'h catchment (Figures $2 b$ and $4 b$ ), a reasonable fit was obtained for the upper class (index $>14 \cdot 5$ ). This was not so for the lower class (index $<10 \cdot 1$ ).

The results could be strengthened by a more quantitative approach. This has been performed as follows for the Kervijen catchment: (1) rasterization of the soil map; (2) comparison of the soil map and the wetness

Table III. Contingency table between the different classes of the soil and wetness maps constructed with the topographical index for the Kervijen catchment, expressed as a percentage for each class

\begin{tabular}{lrrrrr}
\hline Soil classes & \multicolumn{3}{c}{ Classes deducted from the topographical index } & Total \\
\cline { 2 - 5 } & $1,2,3$ & 4,5 & 6 & $7,8,9$ & \\
\hline $1,2,3$ & 84 & 59 & 38 & 30 & 69 \\
4,5, & 4 & 13 & 12 & 7 & 5 \\
6 & 1 & 3 & 4 & 8 & 3 \\
$7,8,9$ & 10 & 24 & 46 & 56 & 22 \\
Total & 100 & 100 & 100 & 100 & 100 \\
\hline
\end{tabular}


map constructed with the topographical index on a cell by cell basis (Tables II and III). Eighty four per cent of the well drained soils and $56 \%$ of the poorest drained soils (classes 7,8 and 9) are correctly recognized by the topographic index. Results for the well drained soils are not surprising because they cover the major part of the catchment. The results show a good agreement for the poorest drained soils (classes 7, 8 and 9). Bad results occur for the other classes.

\section{DISCUSSION}

The correspondence between the soil water regime maps and the topographic index (or potential soil water regime) maps is satisfactory for very poorly drained soils. The best results were obtained for the Kervijen catchment. The limit index values are different for the two catchments.

In the Kervijen catchment, the range of elevation is important, the slopes are steep and there are no extensive flat areas. Waterlogging is restricted to the bottomlands, which fits well with the topographic model based on the contributing area concept. Furthermore, there is a clear difference between the intensely waterlogged bottomlands (class 9) and the freely drained slopes. As the median soil water regime class is not present, the limit index value did not need to be defined precisely. The numerical comparison allows the results to be confirmed; nevertheless, two problems have to be solved before more relevant numerical results can be obtained for the waterlogged soils, as has been emphasized, for instance, by Bruneau (1992), in similar work: (1) degradation of the information during the rasterization of the soil map; and (2) a problem due to the boundaries of the units of waterlogged soils - these units generally consist of narrow elongated strips and therefore the numerical comparison is fairly sensitive to the exact location of the units.

The different results obtained for the Crac'h catchment can be explained by relief and errors in the DTM. First, the relief is gentle and shows large plateau areas. The soil water regime class 6 , the most important in the catchment, is typical of plateau soils characterized by poor lateral and vertical drainage. The poor vertical drainage is only due to soil properties and cannot be modelled correctly from topographic considerations. Pseudogley and gley development (classes 7,8 and 9), located in the bottomlands, is better predicted by the model. Some of the lack of fit may also be due to inaccuracies in the soil unit delineation determined by the soil survey (Walter, 1990), especially as it was carried out by different surveyors. Second, the contour line density of the topographic map is low because of the small elevation gradient of the catchment. The DTM that was derived from this map was not very accurate, except in the confined valley bottoms.

The numerical comparison of the two types of maps, not described here, gave bad results because of the narrowness of the strips of waterlogged soils; that strengthens the reasons emphasized for the Kervijen catchment.

\section{Limit values}

The difference between the index limit values corresponding to intense soil water regime classes is related to the difference in catchment bedrock. In Brittany, the granitic soils are typically more permeable than the soils on Brioverian shale. This is due to a coarser texture and the presence of granite sand. In identical topographic conditions, the soils on shale are saturated earlier than the soils on granite and are thus hydromorphic. This is why the limit index values are higher in the Crac'h catchment; larger drainage area and/or gentler slopes are necessary to reach the same potential waterlogging as in Kervijen. The work reported here must be considered as a calibration phase. The trends and quality of the relationships must be assessed further during a validation phase on other catchments.

The method could be improved by using an index taking into account the transmissivity and effective rainfall rather than the topography index. The contributing area, $a$, can be weighted by the effective rainfall (rainfall minus evaporation) and the slope angle by the transmissivity, as in the soil-topographic index. This would allow the differences between the index limit values corresponding to intense waterlogging classes for catchments presenting contrasting effective rainfall and transmissivity to be standardized. However, maps of numerous catchments are needed for the calibration and validation of such an approach.

The limitations of the method are: (1) conceptual limitations - the index does not account for some major factors leading to the development of waterlogging such as the amount of rainfall, soil surface properties and 
the structure of the agricultural landscape (e.g. hedges; see Merot and Bruneau, 1993) and agricultural drainage; and (2) limitations linked to DTM processing - the topographic index value, and especially the slope angle, depend on the DTM grid size and the larger the grid size, the smaller are the slope angles. This leads to an overestimation of the index. Grid size has to be determined according to the landscape structure; here, a $40 \mathrm{~m}$ grid size appeared to be fine enough for the study catchments. A coarser grid would have altered the information by overlooking the minor valley bottoms.

\section{CONCLUSIONS}

The statistical and spatial distributions of the topographic index and of the soil water regime were compared in two catchments with contrasting relief, bedrock and soils. The index has been related to a specific type of waterlogging, i.e. positional waterlogging.

This comparison shows the relevance of the model used, at least for intense waterlogging. Soils with intense waterlogging in bottomlands are the pedological evidence of quasi-permanent contributing areas. The results emphasize the major role of topography in natural systems and the close connection between the structure of soil cover, the features of the landscape and water movement within catchments.

The approach proposed here is relevant to modelling the distribution of intensely waterlogged soils, provided the relationship between bedrock and the limit values is established. This approach can be applied for several purposes, i.e. from a pedological point of view: (1) to distinguish positional waterlogging from other types of waterlogging; (2) to control the quality and consistency of soil water regime maps; and (3) to create soil water regime maps for non-surveyed catchments. Conversely, from an hydrological point of view, soil water regime maps can be compared with contributing areas simulated by hydrological distributed models for validation purposes.

This study needs to be extended to other types of bedrock and soil covers to allow the method to be used to generate maps of potential waterlogging. Further developments will need to take into account soil transmissivity and rainfall to provide a more meaningful determination of the limit index class values corresponding to soil water regime classes.

\section{ACKNOWLEDGEMENTS}

P. Durand is gratefully acknowledged for useful suggestions and help in the translation.

\section{REFERENCES}

Betson, R. P. 1964. 'What is watershed runoff?', J. Geophys. Res., 69, 1541-1552.

Beven, K. J. 1986a. 'Runoff production and flood frequency in catchments of order $\mathrm{n}$ : an alternative approach', in Gupta, V., Rodriguez-Iturbe, I. and Wood, E. (Eds), Scale Problems in Hydrology, pp.107-131.

Beven, K. J. 1986b. 'Hillslope runoff processes and flood frequency characteristics', in Abraham, A. (Eds), Hillslope Processes. Allan \& Unwin, Boston. pp.187-202.

Beven, K. J. and Kirkby, M. J. 1979. 'A physically based, variable contributing area model of basin hydrology', Hydrol. Sci. Bull., 24, 43-69.

Beven, K. and Wood, E. F. (1983). 'Catchment geomorphology and the dynamic of runoff contributing areas', J. Hydrol., 65, $139-150$. Bruneau, P. 1992. 'Modélisation hydrologique distribuée. Influence de la topographie et des sols et application au transfert de nitrates', Thèse, Université Pierre et Marie Curie, Paris, 210 pp.

Cappus, P. 1960. 'Etude des lois de l'écoulement. Application au calcul et à la prévision des débits. Bassin expérimental d'Alrance', Houille Blanche, 60, 493-520.

Duchaufour, P. 1983. Pédologie. Vol. 1. Masson, Paris. 490 pp.

Hewlett, J. D. 1974. 'Comment on letters relating to role of subsurface flow in generating surface runoff. 2. Upstream source areas by Allan Freeze', Wat. Resour. Res., 10, 606-607.

Hewlett, J. D. and Troendle, C. A. 1975. 'Non-point and diffuse water sources: a variable source area problem' in Irrigation and Drainage Division Symposium, ASCE, Logan, 11-13 August 1975, Watershed Management, 46 pp.

Jamagne, M. 1967. 'Bases et techniques d'une cartographie des sols', Ann. Agron., 18.

Kirkby, M. J. and Chorley, R. J. 1967. 'Throughflow, overland flow and erosion', Bull. Int. Assoc. Sci. Hydrol., 12, 5-21.

Marsman, B. A. and De Gruijter, J. J. 1986. 'Quality of soil maps. A comparison of survey methods in a sandy area', Soil Survey Papers, No. 15. Netherlands Soil Suvey Institute, Wagenigen. $103 \mathrm{pp}$.

Merot, Ph. 1988. 'Les zones de source à surface variable et la question de leur localisation', Hydrol. Continent., 3, $105-115$. 
Merot, Ph. and Bruneau, P. 1993. 'Sensitivity of Bocage landscape to surface run-off: application of Kirkby index', Hydrol. Process., 7, 167-176.

Moore, I. D., Mackay, S. M., Wallbrink, P. J., Burch, C. J. and O'Loughlin, E. M. 1986. 'Hydrologic characteristics and modelling of a small forested catchment in south eastern New South-Wales. Pre-logging conditions,' J. Hydrol., 83, 307-335.

Moore, I. D., Gessler, P. E., Nielsen, G. A. and Peterson, G. A. 1992. 'Terrain analysis for soil specific crop management' in Soil Specific Crop Management; a Workshop on Research and Development Issues. Minnesota Extension Service, University of Minnesota (Agriculture), Minneapolis 23pp.

Quinn, P. F., Beven, K. J., Chevallier, P. and Planchon, O. 1991. 'The prediction of hillslope flow paths for distributed hydrological modelling using digital terrain models,' Hydrol. Process., 5, 59-79.

Rivière, J. M., Tico, S. and Dupont, C. 1992. Méthode Tarière, Massif Armoricain. Caractérisation des Sols. ENSA-INRA Rennes, CRA Bretagne, 21pp.

Squividant, H. 1992. MNTSURF, Logiciel de Création et de Traitement de Modèles Numériques de Terrain, Notice d'Utilisation. INRAENSA, Laboratoire Science due Sol, Rennes. $20 \mathrm{pp}$.

Thomasson, A. J., Mackney, D., Trafford, B. D. and Walpole, R. A. 1975. 'Soils and field drainage,' Soil Surv. Tech. Monogr. No. 7, $80 \mathrm{pp}$.

Vizier, J. F. 1990. 'Eléments pour l'établissement d'un référentiel pour les sols hydromorphes' in Référentiel Pédologique Francais, 3ième Proposition, Avril 1990.AFES, INRA. pp. 253-270.

Walter, C. 1990. 'Estimation des propriétés du sol et quantification de leur variabilité à moyenne échelle: cartographie pédologique et géostatistique dans le sud de l'Ille et Vilaine (France)', Thèse, ENSA-INRA, Rennes. 172pp.

Ward, R. C. 1982. The Fountain of the Deep and the Windows of Heaven: Perplexity and Progress in Explaining the Response of Rivers to Precipitation. University of Hull, 30pp. 